Jurnal Kesehatan Masyarakat

\title{
Knowledge and Attitudes with HIV/AIDS on Adolescent Behavior in Senior High School
}

\author{
Yuneti Octianus Nyoko $₫$, Maria Kareri Hara \\ Poltekkes Kemenkes Kupang, Indonesia
}

\section{Article Info}

Article History:

Submitted July 2019

Accepted April 2020

Published July 2020

Keywords:

HIV/AIDS Behavior,

Student, Knowledge

DOI

https://doi.org/10.15294/

kemas.v16i1.19928

\begin{abstract}
In East Sumba 2016 there were 111 HIV / AIDS patients. Of that number, majority is 2535 years old $(51.4 \%)$ and the most is in Kambera District (28.8\%). These studies are to know the relationships between knowledge and attitudes with HIV/AIDS behavior adolescent in senior high school in Kambera District, East Nusa Tenggara Regency. Crosssectional design. The samples are 132 students of Public Senior High School 1 Kambera, Christian Senior High School Payeti and Public Senior High School Vocational 5 Waingapu. The independent variables are knowledge and attitude and the dependent variable are behavior. Analised data use univariate, bivariate and multivariate. Majority of sample from Public Senior High School Vocational 5 Waingapu (37.9\%), technical majors (37.9\%), male (55.3\%), 17 years old (50.8\%), number of sources of information from one source (25.0\%). Most of the students had less knowledge (68,9\%), less attitude $(63,6 \%)$ and less behavior $(62,1 \%)$. Bivariate analysis showed good knowledge related 4 times to good behavior ( $\mathrm{PR}=3,621 ; 95 \% \mathrm{CI}=2,341-5,601$; $\mathrm{p}$-value $<0,001)$; good attitude related 3 times to good behavior ( $P R=3,111 ; 95 \% C I=1,972-4,907$; $p$-value $<0.001$ ). Multivariate analysis showed that knowledge was the most relationships with behavior (PR:8,659;95\%CI: 3,315-22,618; p-value $<0,001$ ) and then attitude (PR:3.075;95\% CI: $1,162-8,136 ;$;-value 0,024$)$. Schools, government and health services should improve students' knowledge and students are more active in finding information about HIV/ AIDS.
\end{abstract}

\section{Introduction}

East Nusa Tenggara (NTT), which is one of the provinces in the eastern part of Indonesia which ranks 17th out of 33 provinces with the number of HIV cases: 1,751 and AIDS: 496. HIV / AIDS cases in East Sumba Regency which is one of the districts in NTT continue has increased from year to year, namely in 2012 the number of cases of HIV: 16 and AIDS: 9, in 2013 the number of cases of HIV: 23 and AIDS: 13, in 2014 the number of cases of HIV: 10 and AIDS: 15 and in 2015 the number of cases of HIV: 10 and AIDS: 19 number of HIV cases (Health Office of East Sumba District, 2015). From this number of cases, it was found that as many as $51.4 \%$ of cases occurred in productive ages, namely 25-35 years (Yuneti, 2016). This trend shows that age 20-35 years are mostly affected by HIV / AIDS. This shows that sufferers have been exposed to the HIV virus at the age of 15-17 years old because AIDS takes 8-10 years to show clinical symptoms since being first infected (Hutapea et.al, 2012). These ages are a category of adolescents who are still pursuing high school education (SMA). The results showed that in East Sumba, the most cases occurred in Kambera Subdistrict as many as 32 cases out of 111 cases or $28.8 \%$ (Yuneti, 2016). In this sub-district there are 3 Senior high schools namely Senior high school 1 
Kambera, Senior high school of Cristian Payeti and vocational high school 5 Waingapu.

Knowledge is a predisposing factor that can influence a person's behavior to change. The correct knowledge about HIV and AIDS in adolescents can help adolescents avoid behaviors that are at risk of contracting HIV / AIDS. Knowledge of adolescents in general about health, especially reproduction, can be influenced by their education, personal experiences of adolescents, their culture and the mass media they are exposed to. Adolescents who have good reproductive health education especially will have good behavior also related to HIV / AIDS compared to negative attitudes (Lou et al., 2012). Adolescents are vulnerable to HIV / AIDS because, in general, adolescents are sexually active, but teenagers often get insufficient information about maintaining reproductive health, difficulty negotiating sex with a boyfriend and often difficulties in getting reproductive health services such as HIV / AIDS. If from an early age, adolescents do not receive accurate and correct information about HIV / AIDS, it can cause adolescents to become a sub-population who behave at high risk of HIV / AIDS. Based on this, a study was conducted on the relationship of knowledge and attitudes with adolescent attitudes about HIV / AIDS in Senior high school in Kambera District, East Sumba Regency.

Method

This type of research is an analytic study with a cross-sectional design. The sample of this research was 132 students at Senior high school in Kambera District, East Sumba Regency, namely Senior high school 1 Kambera, Senior high school Christian Payeti and Vocational high school 5 Waingapu. The research was conducted in August 2017. The independent variables measured were knowledge and attitudes. The knowledge that is measured is the knowledge of students about the meaning, mode of transmission, prevention, treatment and clinic of VCT. The attitudes measured were students' attitudes about pornography, free sex, drug use, stigma and discrimination against people with HIV / AIDS. The dependent variable is student behavior related to HIV / AIDS in the form of student sexual behavior. Data collection was carried out by interview using a questionnaire that has been tested for validation. The criteria for respondents were high school students in class XI and willing to be interviewed. The sampling technique was simple random sampling. Data analysis was performed univariate, bivariate using the chisquare statistical test and multivariate using the Binary Logistic Regression test with the Enter method.

\section{Results and Discussion}

A total of 132 students were interviewed and continued with analysis. Based on the analysis results obtained the most students came from vocational high school 5 Waingapu (37.9\%), most from the engineering department (37.9\%), males $(55.3 \%)$, aged 17 years $(50.8 \%)$.

The results of the univariate analysis showed that most of the 132 students had poor knowledge of HIV / AIDS in Senior high school in Kambera District, East Sumba Regency (68.9\%). This result is in accordance with research in Senior high school in Banjarmasin which shows that most students, namely $82.10 \%$, have a low level of knowledge about HIV / AIDS (Ningtyas, 2014; Dewi, 2017), and research at Senior high school of Cristian Eben Haezar Manado which states that of students, namely 50.5\% have less knowledge about HIV / AIDS (Reynaldi, 2013). This result is also in line with research in Saudi Arabia which showed $64.5 \%$ of respondents had poor knowledge of HIV / AIDS (Alawad, 2019).

Students at SMA of Kambera Regency, East Sumba Regency, the most lack of knowledge about the clinic of Voluntary Counseling and Testing (VCT), anti-retroviral drugs given to HIV / AIDS sufferers and when a person is infected with HIV until someone develops symptoms of HIV / AIDS. This low knowledge does not match the age of the students, most of whom are 17 years old (50.8\%), which should be that at these ages adolescents try to find new experiences and new information (Pawesti, 2013). This low knowledge can be influenced by gender, where in this study most were males (55.3\%). Women are psychologically more motivated and more diligent in learning and seeking information than men. This is supported by research that shows young women have a better level of knowledge about HIV-AIDS than young men 
Table 1 Distribution of Respondents based on School Origin, Department, Gender and Age of Senior High School Students in Kambera District, East Sumba Regency

\begin{tabular}{lll}
\hline Characteristics & $\begin{array}{l}\mathrm{n} \\
(\mathrm{N}=132 \text { People })\end{array}$ & $\%$ \\
\hline Schools & & \\
Senior high school 1 Kambera & 37 & 28,0 \\
Senior high school of Cristian Payeti & 45 & 34,1 \\
Vocational high school 5 Waingapu & 50 & 37,9 \\
Department & & \\
Natural science & 25 & 18,9 \\
Social science & 37 & 28,0 \\
Language & 20 & 15,2 \\
Engineering & 50 & 37,9 \\
Gender & & \\
Male & 73 & 55,3 \\
Female & 59 & 44,7 \\
Ages & & \\
15 Years old & 8 & 6,1 \\
16 Years old & 24 & 18,2 \\
17 Years old & 67 & 50,8 \\
18 Years old & 29 & 22,0 \\
19 Years old & 4 & 3,0 \\
\hline
\end{tabular}

Source: Primary Data, 2017

Table 2. Univariate Analysis of Knowledge and Attitudes with Adolescent Behavior Related to HIV / AIDS in Senior high school in Kambera Subdistrict, East Sumba Regency

\begin{tabular}{lll}
\hline Variable & $\begin{array}{l}\mathrm{n} \\
(\mathrm{N}=132 \text { People })\end{array}$ & $\%$ \\
\hline Knowledge & & \\
Good & 41 & 31.1 \\
Less good & 91 & 68.9 \\
Attitude & & \\
Good & 48 & 36.4 \\
Less good & 84 & 63.6 \\
Action & & \\
Good & 50 & 37.9 \\
Less good & 82 & 62.1 \\
\hline Source Primary
\end{tabular}

Source: Primary Data, 2017

(Nurwati, 2018). This low knowledge could also be caused by the fact that most students only received information from one source, namely health workers $(25.5 \%)$, this could be due to a culture of taboo in talking about sexual behavior. The fewer sources of information, the less information obtained because exposure to information will affect knowledge about AIDS / IMS (Lou et al., 2012). Another thing that causes low knowledge is that in various HIV /
AIDS counseling, it is still about the definition, risk factors, prevention but lack of information about HIV treatment and also places where people can get checked out if they have HIV / AIDS symptoms.

The results of the univariate analysis also showed that most of the students had unfavorable attitudes regarding HIV / AIDS in Senior high school in Kambera District, East Sumba Regency (63\%). This result is the 
same as the study in Manado which showed $44 \%$ of students had a bad attitude towards HIV / AIDS (Manafe, 2014). This result is also in line with research in Saudi Arabia which shows $67.4 \%$ of respondents have a bad attitude towards HIV / AIDS (Alawad, 2019). This lack of attitude can be influenced by a lack of knowledge. Good knowledge can have a positive effect on the formation of adolescent attitudes. This was stated in the study which showed that there was a significant relationship between the level of knowledge about sex with the attitudes of students at Senior high school 1 Kandanghaur toward free sex outside of marriage (Handayani, 2015). Knowledge, apart from influencing attitudes to prevent free sex outside of marriage, knowledge also affects adolescent attitudes towards people living with HIV / AIDS (ODHA). In this research, it was found that students with low knowledge had a higher stigma against ODHA than students with high knowledge. This is in line with research on adolescents in Surakarta (Sosodoro, 2009).

The majority of adolescent behaviors behave poorly (62.1\%). The results of this study are in line with research showing poor adolescent behavior towards HIV / AIDS (Zeth, 2010; Sofni, 2015; Afritayeni, 2018). Risk behavior is any behavior or action that increases a person's chances of contracting or transmitting a disease such as HIV. Some examples of risky behavior in the context of HIV include having unprotected sex, especially with multiple partners and sharing injections.

Table 3. Distribution of Number of HIV / AIDS Information Sources Providing Knowledge to Senior High School Students in Kambera District, East Sumba Regency

\begin{tabular}{lll}
\hline $\begin{array}{l}\text { Number of sources of information on HIV / } \\
\text { AIDS that provide knowledge }\end{array}$ & $\begin{array}{l}\mathrm{N} \\
(\mathrm{N}=132 \text { People })\end{array}$ \\
\hline 1 & 33 & 25.0 \\
2 & 12 & 9.1 \\
3 & 9 & 6.8 \\
4 & 22 & 16.7 \\
5 & 18 & 13.6 \\
6 & 18 & 13.6 \\
7 & 12 & 9.1 \\
8 & 8 & 6.1 \\
\hline
\end{tabular}

Source: Primary Data, 2017

Table 4.Bivariate Analysis of Knowledge and Attitudes with Adolescent Behavior Related to HIV / AIDS in Senior High Schools in Kambera District, East Sumba Regency

\begin{tabular}{lllllll}
\hline \multirow{5}{*}{ Variable } & \multicolumn{2}{l}{ Behavior } & & & \\
\cline { 2 - 4 } & Good & Less good & Total & P5\%CI & p-value \\
\cline { 2 - 4 } & $\mathrm{n}(\%)$ & $\mathrm{n}(\%)$ & $\mathrm{n}(\%)$ & & \\
\hline Knowledge & & & & 3,621 & $2,341-5,601$ & $<0,001$ \\
$\quad$ Good & $31(75.6)$ & $10(24.4)$ & $41(100)$ & & & \\
Less good & $19(20.9)$ & $72(79.1)$ & $91(100)$ & & & \\
Total & $50(37.9)$ & $82(62.1)$ & $132(100)$ & & & \\
Attitude & & & & 3,111 & $1,972-4,907$ & $<0,001$ \\
$\quad$ Good & $32(66.7)$ & $16(33.3)$ & $48(100)$ & & & \\
$\quad$ Less good & $18(21.4)$ & $66(78.6)$ & $84(100)$ & & & \\
Total & $50(37.9)$ & $82(62.1)$ & $132(100)$ & & & \\
\hline
\end{tabular}

Source: Primary Data, 2017 
This behavior can occur due to many factors, including the adolescent's knowledge of the causes of HIV / AIDS, modes of transmission and how to prevent HIV / AIDS itself. This lack of knowledge and understanding can lead adolescents to unhealthy behaviors that put them at risk for contracting HIV / AIDS because bad behavior can be caused by a person's lack of knowledge.

Chi-square test results showed that good knowledge was 4 times related to good behavior related to HIV / AIDS in Senior high school, Kambera District, East Sumba Regency and this relationship was statistically significant $(\mathrm{PR}=3,621 ; 95 \% \mathrm{CI}=2,341-5,601$; $\mathrm{p}$-value $<0.001)$. This is in line with several studies which state that there is a relationship between knowledge and premarital sexual behavior in adolescents (Indratmoko, 2013; Kumalasari, 2016; Rahayu, 2017; Aziz, 2018). The results of overseas research also found that there was a low relationship between awareness and negative HIV / AIDS behavior (Thanavanh, 2013; Salman, 2018; Seo Min, 2018). This shows that the higher the knowledge of adolescents, the lower the sexual behavior before marriage, conversely, the lower the knowledge, especially about sexual health in adolescents, the higher the sexual behavior before marriage.

Reproductive health knowledge is very important for adolescents because adolescence is an age stage that experiences a lot of development, both biology and psychology. One of the factors that influence adolescent knowledge is information received from parents, friends, closest people, the mass media or from discussions. The low level of knowledge among adolescents is due to the lack of information received by adolescents. Teenagers receive more information from electronic media such as television, via cellphones, etc. Most of the information on television is limited to premenstrual syndrome and HIV-AIDS, while information on sexual and reproductive health is still rare. The assumption that talking about sexual health is shameful and taboo for families and society makes young people who lack information try on their own to find information on their own, sometimes the information obtained is actually wrong and misleading. Half-assed sexual knowledge not only encourages teenagers to experiment, but can also lead to misperceptions. A person's level of knowledge can influence a person to take action (Nubed, 2016; Jaelani, 2017), because knowledge is the foundation for the formation of behavior so that the higher the level of one's knowledge, the less likely it is to engage in sexual behavior outside of marriage (Notoadmojo, 2010). Behaviors that are carried out based on good knowledge will last longer than behavior carried out by not using the correct knowledge base.

Chi-square test results also showed that a good attitude was three times related to good behavior related to HIV / AIDS in Senior high school in Kambera District, East Sumba Regency and this relationship was statistically significant $(\mathrm{PR}=3.111 ; 95 \% \mathrm{CI}=1.972-4.907$; $\mathrm{p}$ - value $<0.001)$. This is in line with research that shows a significant relationship between attitudes and HIV / AIDS behavior (Indratmoko, 2013; Tampi, 2013; Kumalasari, 2016; Aziz, 2018;). The results of overseas research also found that there was a relationship between negative attitudes and negative behavior with HIV / AIDS (Thanavanh, 2013; Seo Min, 2018). The more permissive is (unfavorable attitude) to sexual behavior, the greater the behavior of adolescents in having physical relationships with their boyfriends. This means that the less good the adolescent's attitude towards sexual behavior, the greater the chance for adolescents to engage in HIV / AIDS risky behavior, on the contrary, the better the adolescent's attitude, the less the chance for adolescents to engage in HIV / AIDS risk behavior. Attitudes are important not only because they are difficult to change, but because attitudes greatly influence thinking and have an impact on individual behavior, especially when attitudes are strong. Attitude is a predisposition (determinant) that gives rise to behavior in accordance with the attitude. This is also in accordance with the theory that predisposing factors in this case are related to one's behavior (L. Green, 1999). Attitudes are preceded by understanding and knowledge that is perceived through something that is good and true or not good and then internalized into him (Dalimunthe, et al, 2012). Knowledge, thoughts, beliefs, and emotions play an important role in determining a complete attitude. For example, 
Table 5.Multivariate Analysis of Knowledge and Attitudes with Adolescent Behaviors Related to HIV / AIDS in Senior High Schools in Kambera District, East Sumba Regency

\begin{tabular}{lllllll}
\hline Variable & $\mathrm{B}$ & $\mathrm{SE}$ & Wald & $\mathrm{p}$-value & PR & $95 \% \mathrm{CI}$ \\
\hline Knowledge & 2,159 &, 490 & 19,415 & $<0,001$ & 8,659 & $3,315-22,618$ \\
Attitude & 1,123 &, 494 & 5,262 & 0,024 & 3,075 & $1,162-8,136$ \\
\hline
\end{tabular}

Source: Primary Data, 2017

a teenager has heard of HIV / AIDS (its causes, consequences, prevention, and part of it) then this knowledge will lead the teenager to think and try so that he does not contract HIV / AIDS. In thinking, the components of emotion and belief come to work so that the teenager intends to take precautions so that he does not contract HIV / AIDS. This teenager has a certain attitude towards objects in the form of HIV / AIDS. Therefore, the knowledge of adolescents needs to be improved and the results of this study can be used as a basis for increasing the provision of information to students on a regular basis, both by the school and by the health service regarding the knowledge of HIV / AIDS as a whole and students can be more active in seeking information. especially about health in the existing media, so they can have good and correct knowledge and understanding of HIV / AIDS so that the risks of contracting HIV / AIDS can be avoided.

The results of the multivariate analysis showed that the variable most associated with the behavior of students related to HIV / AIDS was knowledge, namely good knowledge was 9 times related to the good behavior of students related to HIV / AIDS (PR: 8,659; 95\% CI: 3,315-22,618; p -value <0.001), then the attitude variable, namely a good attitude, was three times related to the good behavior of students related to HIV / AIDS (PR: 3.075; 95\% CI: 1.162-8.136; p-value 0.024). Therefore, knowledge and attitude factors must be improved to reduce HIV-related behavior. This is in line with Notoadmojo's (2010), which states that knowledge or cognition is a very important domain for the formation of one's actions (overt behavior). Good knowledge will form a good attitude and a good attitude will form good action too. Improved education is needed to produce adolescents who behave well towards HIV / AIDS.

\section{Conclusion}

Knowledge and attitudes are related to adolescent behavior related to HIV / AIDS in Senior high school in Kambera District, East Sumba Regency. Respondents who have good knowledge are related 3,621 times with good behavior and good respondent attitudes are related 3,111 times with good behavior. Schools, government and health services must continue to strive to improve student knowledge and students are more active in seeking information about HIV / AIDS.

\section{Acknowledgments}

We thank the Health Development Research (Risbinakes), Health Polytechnic of the Ministry of Health, Kupang, who funded this research. We also thank the Study Program for their assistance and support during the research.

\section{References}

Alawad, M., Alturki, A., Aldoghayyim, A., Alrobaee, A., \& Alsoghair, M., 2019. Knowledge, Attitudes, and Beliefs about HIV/AIDS and People Living with HIV among Medical Students at Qassim University in Saudi Arabia. Internasional Journal of Health Sciences (Qassim), 13(5), pp.22-30.

Azis, S.R.H., Budi, T., \& Ratag, A.A., 2018. The Relationship Between Knowledge and Attitudes About Reproductive Health With Premarital Sexual Behavior In Adolescents At the boarding house in Kleak village, Manado City. Journal of Public Health, 7(4), pp.1-8.

Afritayeni., Yanti, P.D., \& Angrainy, A., 2018. Analysis of Sexual Risk Behavior in Adolescents Infected with HIV and AIDS. Jurnal Endurance, 3(1), pp.69-81.

Dalimunthe., Rukmana, C., \& Na-deak, K., 2012. Knowledge Level of Senior high school Students Harapan-1 Medan About Free Sex with the Risk of HIV / AIDS. EJournal FK USU, 1(1),pp.1-6.

East Sumba District Health Office., 2015. HIV / AIDS Report for East Sumba Regency 20122015. 
Depkes RI., Pusat Data and Informasi., 2014. Situation of HIV / AIDS in Indonesia, 20062014.

Dewi., Rustiari, N.L.P., \& Wirakusuma, I.B., 2017. Knowledge and Premarital Sexual Behavior in High School Adolescents in the Work Area of Health Center in Tampaksiring I. E-Jurnal Medik, 6(10),pp.50-54.

Hutapea., Desima, M., Sarumpaet, S.M., \& Rasmaliah., 2012. Characteristics of HIV / AIDS Patients in the VCT Clinic at the General Hospital of HKBP Balige. EJournal of FK USU,1(1), pp.20-35.

Handayani, S., \& Setyawa, F., 2015. Relationship between Knowledge and Premarital Sex Attitudes in Senior high school Students I Kandanghaur Indramayu. Journal of Public Health, 1(2), pp.1-6.

Indratmoko, W., 2013. The Influence of Knowledge, Attitudes, and Self-Motivation Against HIV / AIDS Prevention Behavior in Urban High School Students in Sragen Regency. Journal of Health of Muhammadiyah Surakarta, 6(1), pp.1-6.

Jaelani, A.K., Putri, M., \& Lubis, N.A., 2017. The Relationship between Maternal and Childbirth Knowledge About Balanced Nutritional Food with Perineal Wound Healing in the Work Area of the Public Health Center in Sipayung Indragiri Hulu. Jurnal Endurance, 2(1), pp.31- 36.

Kumalasari, D., 2016. The Relationship between Knowledge and Attitudes and Sexual Behavior in Vocational School Students. Journal of Aisyah: Journal of Health Sciences, 1(1), pp.1-6 .

Lou, C., Cheng, Y., Gao, E., Zuo, X., Emerson, M.R., \& Zabin, L.S., 2012. Media's Contribution to Sexual Knowledge, Attitudes, and Behaviors for Adolescents and Young Adults in Three Asian Cities. J Adolesc Health, 50(3), pp.2636.

Manafe., Leni, A., Kandou, G.D., \& Posangi, J., 2014. The Relationship between Knowledge, Attitudes, the Role of Teachers, Information Media (Internet) and the Role of Peers with HIV/AIDS Prevention Measures in Students at Senior High School 4 Manado. JIKMU, Suplemen, 4(4), pp.644-655.

Ningtyas, N., Noor, R.M., \& Triawanti., 2014. Level of Knowledge About HIV / AIDS in Public High School Students in Banjarmasin in 2013. Publisher: Journal of Periodic Medicine,10(1), pp.121-132.

Notoatmodjo, S., 2010. Health Research Methodology. Rineka Cipta Publisher. Jakarta
Nubed., Kingoum, C., \& Jane-Francis, T.K.A., 2016. Knowledge, Attitudes and Practices Regarding HIV/AIDS among Senior Secondary School Students in Fako Division, South West Region, Cameroon. BMC Public Health, 16(1), pp.847.

Nurwati, N., \& Rusyidi, B., 2018. Knowledge of Youth Against HIV-AID. Journal of Unpad Proceedings of Research \& Community Service, 5(3), pp.288-293.

Pawesti., Wardani, R.S., \& Sonna., 2013. Knowledge, Attitudes and Behavior of Teens About Sex of Pre Marriage. Journal of Maternity Nursing, 1(1), pp.46-54.

Rahayu, I., 2017. Hubungan Tingkat Pengetahuan Tentang HIV/AIDS Dengan Perilaku Seksual Pranikah Pelajar. Journal Endurance, 2(2), pp.145-150.

Reynaldi, R.H., Grace, D.K., \& Benny, S.L., 2013. Relationship of Characteristics, Knowledge, and Use of Information Technology with HIV / AIDS Risk Behavior among Christian High School Students in Eben Haezar Manado. Publisher: Journal of Community Medicine And JKKT Tropics, 1(1), pp.1-6.

Salman, Z.U., Mustafa, M.M.S.K., Afridi, N., Asif, N., Shehzadi., \& Hussain, K., 2018. A Cross-sectional Assessment of Knowledge, Attitudes and Beliefs Concerning HIV/AIDS among Pakistani University Population. Indian Journal of Pharmaceutical Sciences, 80(1), pp.210-214.

Soe Min, Oo., 2018. HIV/AIDS-related Knowledge, Attitudes, Behavior and HIV testing status among Young People in Myanmar. Publications: University of California, 6(1), pp.1-27.

Sofni., Meyrisa, L., Dewi, Y.I., \& Novayelinda, R., 2015. Comparison of Knowledge and Attitudes Between Young Men and Young Women About HIV / AIDS Prevention Measures. Student Online Journal (JOM), University of Riau, 2(2), pp.1241-1249.

Sosodoro, O., Emilia, O., \& Wahyuni, B., 2009. The Relationship between Knowledge of HIV / AIDS and the Stigma of People Living with HIV / AIDS among High School Students. Publisher: Community Medical News (BKM), 25(4), pp.210-217.

Tampi, D., Grace, D., Kandou., Gustaaf, E.A., \& Ratag., 2013. The Relationship between Knowledge, Attitudes and HIV / AIDS Prevention Measures in Manado International School High School Students. Journal of Community Medicine and Tropics, 1(4), pp.140-145. 
Thanavanh., Bounbouly, Md., Harun-ArRashid., Kasuya, H., \& Sakamoto, J., 2013. Knowledge, Attitudes and Practices Regarding HIV/AIDS among Male High School Students in Lao People's Democratic Republic. Journal of The International AIDS Society, 16(1), pp.1-7.

Yuneti, O., \& Nyoko., 2016. Characteristics of HIV
/ AIDS Patients in East Sumba 2010-2016. Journal of Primary Health, 1(1), pp.4-15.

Zeth., Arwam, H.M., \& Asdie, A.H., 2010. HIVAIDS Disease Risk and Behavior in Papuan Communities. A Study on the Development of Local Models for HIV-AIDS Policy. Journal of Health Service Management, 13(4), pp.206-219. 